【カテゴリーI】

\title{
建築用外装塗料の耐候性と環境劣化因子による多変量解析 \\ MULTIVARIATE ANALYSIS FOR WEATHERABILITY OF ARCHITECTURAL COATINGS REFERRING EMVIRONMENTAL DEGRADATION FACTORS
}

\author{
平田信 人*1, 樫野紀 元*2, 冨板崇*3 \\ Nobuhito HIRATA, Norimoto KASHINO and Takashi TOMIITA
}

\begin{abstract}
The weatherability of colored architectural coatings is evaluated by a 4-years outdoor exposure test at various areas. Gloss retention, differences of brightness and value $\mathrm{b}^{*}$ along yellow-blue axis were applied by a multivariate analysis referring estimated environmental degradation factors, 1) equivalent environmental temperature based black panel thermometer, 2) solar ultraviolet dose, 3) wetness time and 4) freezing/thawing cycle. Value of delta-L, an element of color difference, of yellow samples modified by those of white one were almost constant and did not related with referred factors. Therefore, the traditional evaluation system based mainly on color difference may be reducing accuracy.
\end{abstract}

\section{Keywards: Anchitectural caating, Weatherability, Multivariate analysis, Environmental degradation factors, Outdoor exposure test, Modified brightness

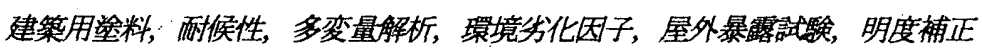

1. はじめに

建筑用塗料の耐候性に関して，屋外暴露試鈳が多く実施されてお り，その結果も多く報告されている ${ }^{1-6)}$ 。その耐候性を評価する指 標として，光沢残存率や色差などがあるが，「色差」については，色 相・彩度・明度の変化量が複合されたものである7)。

屋外暴露試験によってそれらの值が変化する原因は, 前報 ${ }^{8)}$ で塺 埃が付着することで，明度低下を生ずる」ことを指摘したように， 他の要素変化の原因と同じではない。

今回「着色塗料」の屋外暴露試験結果を解析するに際して, 測色 時に得られる明度 ( $L$ 值)，黄 青味の彩度 ( $b^{*}$ 値) を精査したとこ ろ, 顔料種によってそれぞれ特有の変化があることが認められ，「色 差の值」に基の゙くこれまでの耐侯性評価手法の精度を改善する手が かりが得られた。

さらに，著者らは塗料の耐候性に関わる「環境劣化因子」である 紫外線・熱 (温度)・水分など9)を，全国各地における気象観湘結 果から推定しているので,これらを説明変数とする重回㷌式により, 特性変化を表現することを試みた。

\section{2. 試 料}

本報では着色塗料を报うが，展色剂として耐候性が高いとされる
ウレタン樹脂を選定した。これは他の耐候性試験プロジェクト2，3) でも共通である。白色体質顔料として酸化チタンを配合した塗装系 に，表一 1 に示すような $b^{*}$ 值の絶対値が大きい黄色顔料 (有機系と 無機系)・青色顔料 (有機系) と， $L$ 值が小さい黑色顔料を混合した 塗料を調整しここれらを $300 \times 90 \mathrm{~mm}$ の鉄板に塗布した。今回の白 色試料は, 前報 ${ }^{8)}$ の「白色ウレタン樹脂塗料：UE」と同一で, 明 度補正のために参照される。

\section{表一1 供試涪料の穆類}

\begin{tabular}{|c|c|c|c|c|}
\hline 記号 & 色調 & 一般名·組成 & 䫓料 & 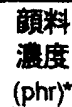 \\
\hline WirT & 白 & $\begin{array}{c}\text { ウレタン榯脂涳料／acrylic } \\
\text { polyol isocyanate 架檽 }\end{array}$ & $\begin{array}{l}\text { titanium } \\
\text { dioxide }\end{array}$ & 80 \\
\hline YEL-O & 黄(有機) & $"$ & $\begin{array}{l}\text { isoindoline } \\
\text { yellow }\end{array}$ & 20 \\
\hline YEL-1 & 黄(無譏) & $"$ & lead chromate & 50 \\
\hline BLU & 青 & $" \prime$ & $\begin{array}{l}\text { phthalocyanine } \\
\text { copper }\end{array}$ & 20 \\
\hline BLK & 黑 & $" \prime$ & carbon black & 5 \\
\hline
\end{tabular}

$\mathrm{phr}$ : 樹脂固形分に対する顔料濃度の百分率

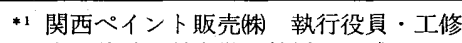

*2 市立前橋工科大学. 教授. 工博

*3ウェザリングワークショップ 工博
Executive Director, Kansai Paint Sales Co., Ltd., M. Eng.

Prof., Maebashi Institute of Technology, Dr. Eng.

Weathering Workshop, Dr. Eng. 


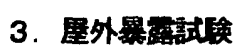

前報8）之同様に，国内の代表的な気候区分に属する，恵庭（北海 道)・つくば (茨城)・大田 (東京) ・平塚 (神奈川) ・尼崎 (兵庫) ・ 沖永良部 (鹿児島) にて; 南 (記号: S) /北 (N) 垂直面に暴露し た。恵庭では 1987 年 9 月より，つくば・大田・尼崎・沖永良部で は同年 10 月より，平塚では同年 11 月より試験を開始して, 1991 年まで 4 年間の 1 年経過每に試料を回収した。(前報8) で「1988 年 10月より訆験を開始」と誤って記したが，本報の通り訂正する。）

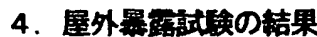

回収された試料を，水道水を流しながらウーローラーを用いて水 洗後に，BYK 社製マイクロトリグロス光沢計を用いて入反射角： $60^{\circ}$ での光沢 (記号: $G$ ) と, Minollta 社製 CR300型 色差計を 用いて明度 $(L)$ ・黄 青軸の彩度 $\left(b^{*}\right)$ を，特異的な変色部分を 避けて，各試料の概数中心部分およびその上下 $10 \mathrm{~cm}$ センチ付近の 3ヶ所を，それぞれ3回測定してこれらを平均化した。前報で提案 したように「白色試料の明度変化量 : $\Delta L_{\mathrm{w}}$ で, 他の試料の明度変化 を補正した後の值（以後，補正後の明度）: $\Delta L-\Delta L_{\mathrm{N}}$ 」も求め た。これらの 4 年経過時点までの屋外暴露試験の結果を表一 2 に示 す。また，暴露地点別に光沢変化の経時変化を図一 1 に，明度と 4 試料の「補正後の明度変化」を図 -2 と図一 3 に，3つの着色試料 の $b^{*}$ 値を図一 4 に示す。
光沢 ……初期段階は緩やかで経年が進むと変化の速度が大きく なる傾向があり，これは指数関数的な変化に似ている。南面が北面 より光沢減少が速く，亜熱帯の沖水良部にて暴露された試料，それ に次いで大田で暴露されたもので速い。

明度 …. 白色試料で補正すると明るい黄色試料 (YEL-O, YEL-I) では 1 年経過後よりほほ一定となる傾向があり，前報で「白色試料 で明度変化が一定となる」ことと共通である。暗色の青色試料 (BLU) と黒色試料 (BLK) では，経過年によって変動はあるが概 ね明度が上昇している。南面が北面より変化が大きいが，沖永良部 では南北であまり差がないことに着目できる。

$b^{*}$ 值 …. 有彩の3 試料 (YEL-O, YEL-I, BLU)については，年数 が増えると絶対值が堿少して彩度が低下する。この指標でも，YEL-I, BLUに関して沖永良部では南北面の差が顥著ではない。

\section{5. 櫭境劣化因子による重回州分析}

高分子素材の屋外耐久性を予測するため，特性変化を作用因子の重 回㷌式で表す手法が提案されている ${ }^{10)}$ 。塗料などの「環境穷化因子」 の主要なものに関して，著者らは気象要素から推定する手法を報告 しており，いくつかの作用因子で南北面のおよその差も把握してい る。前報8)では，気象要素である「降水量」・「日最高気温」・水平 面紫外線量」を用いて重回州分析をおこなっていたが，本報では， 既報に示した「環境少化因子」の推定値，あるいはそれに基づく值

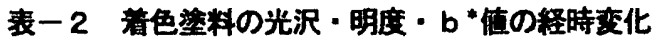

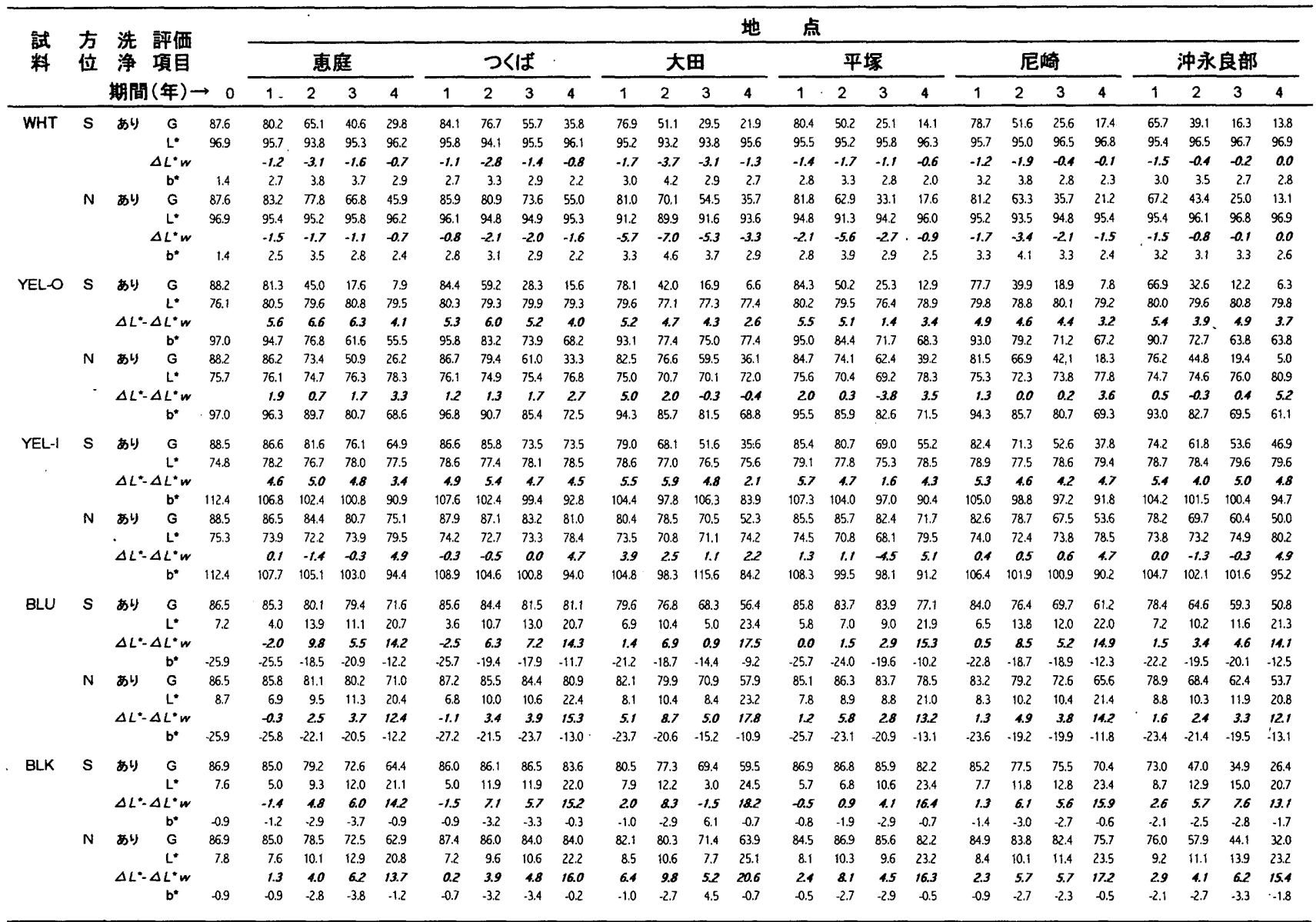

移太字は、白色試料の明度変化量で補正した値 
経過年数: 0224

(年) $|1| 3 \mid$

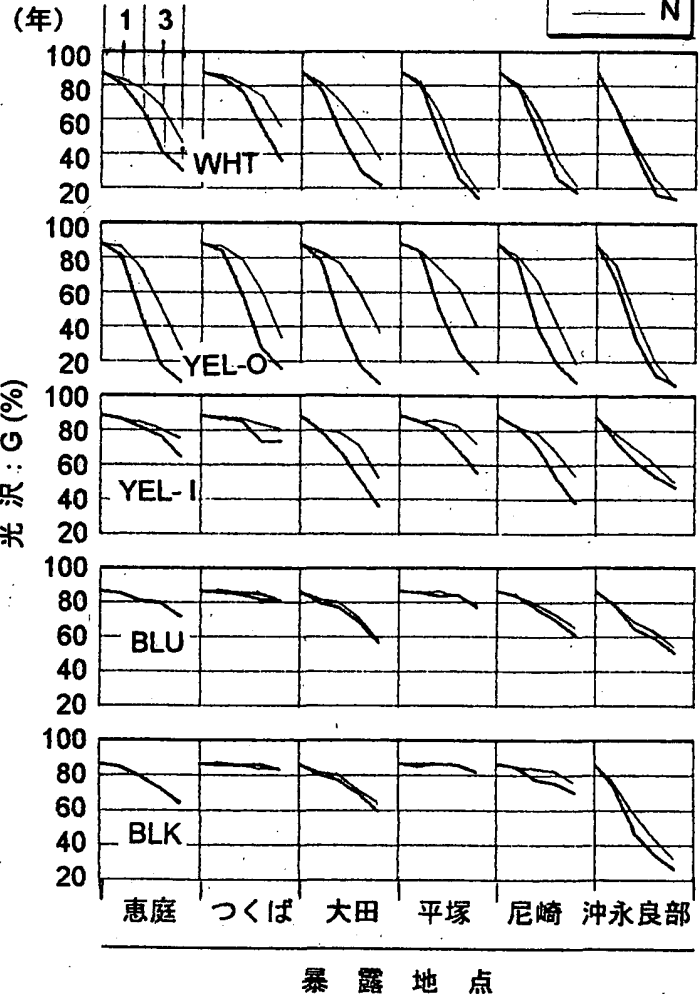

图一 1 光沢度化の地城琹

経過年数: 024

(年) $|1| 3$

$-N$

90

80

70

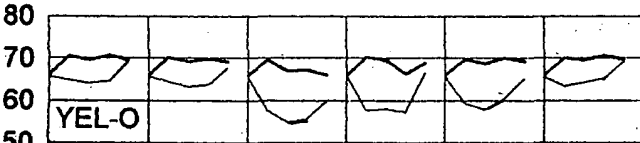

I
$\ddot{1}$
眥
器
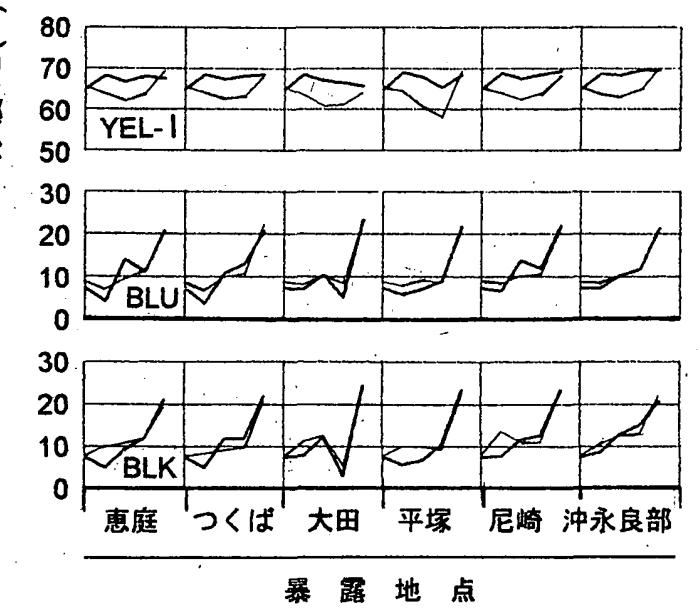

图一2 明度の地城盖

を参照する。

5. 1 環境劣化因子

水分 …. 結露時間, Wetness time (記号 : WT) で定量化され る $^{11}$ が，垂直面ではまだ推定值が得られていないので，暫定的に
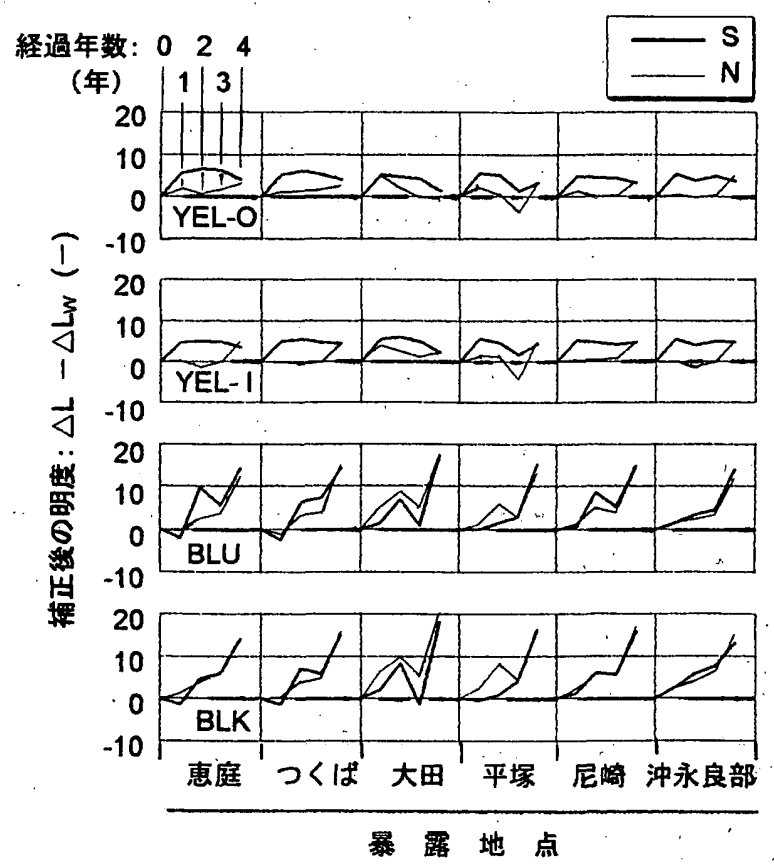

图一3 補正後の明度の地域差

経過年数: 024

(年) $|1| 3 \mid$

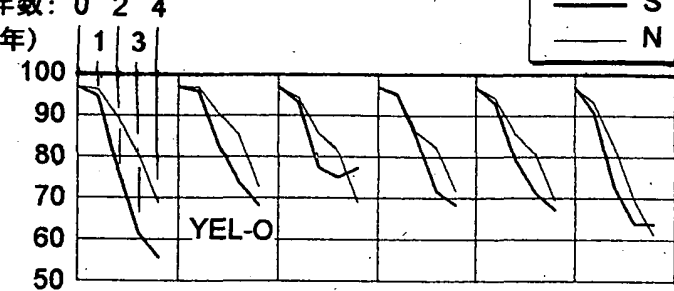

I 1

110
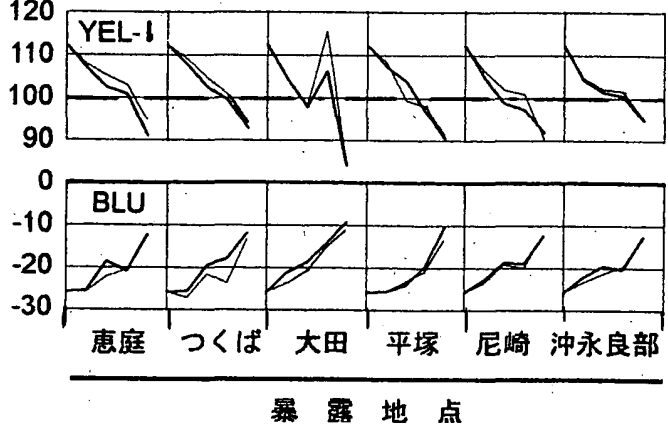

图一－ｂ*值の地域荎

$30^{\circ}$ 面の值を参照する。暴露地点と結露時間の推定地点が離れてい る場合は，当該地点の両側にある気象锶測官署の値を基に，距離に

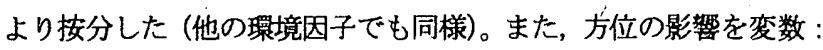
くN>を尊入（南面では 0, 北面では10值)して解析する。

熱（温度） -.--フフラックパネル温度に基づく「熱劣化量マップ・ 南／北垂直面」12）を参照し，変動する気象環境条件下での特性変 化に等しくなるような，仮想の一定温度: 相当環境温度, Equivalent environmental temperature ( $E T)$ を求めた。この指摽は化学反 応速度論に基づき，熱（温度）による促進劣化作用を考慮したもの である。

紫外線量, Solar ultraviolet radiation dose（UV) -...沖永良部 の水平面での推定值が示されている資料 ${ }^{13 !}$ で，暴露地点に最も近 
い気象観測官署での值に基づく。舘野 (茨城県つくば市)において， 水平面 : 南垂直面 : 北垂直面の年間紫外線量の比が $1: 0.67: 0.30$ と推定された ${ }^{14)}$ のでこの比率を乘じた。䋨度や観湘年によって比 率はいくらか異なる。沖永良部での南／北垂直面の紫外線量につい ては，基礎データである全天日射量が観測されていないので，最新 の手法 ${ }^{14)}$ が適用できない。水平面と南北垂值面での紫外線量の比 率も緯度や気候の季節変化で変動し，つくばの值で代替することで 誤差があるのが現状であり，まず「主要な作用因子を抽出する」こ とを第一として，本報の解析ではある程度の誤差は許容した。

凍結融解回数, Freezing/thawing cycle (FZ) -... 氷点温度以下の ブラックパネル温度に基づく「凍結辞解回数マップ・南/北垂直

\section{表一-3 㻴境劣化因子と $\mathrm{SO}_{2}$ 湌度}

\begin{tabular}{|c|c|c|c|c|c|c|c|}
\hline \multirow{2}{*}{$\begin{array}{c}\text { 因子 } \\
\text { (梩号) } \\
\frac{\text { 监位 }}{\text { 方位/角度 }}\end{array}$} & \multirow{2}{*}{ 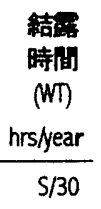 } & \multirow{2}{*}{ 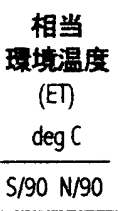 } & \multicolumn{2}{|c|}{$\begin{array}{c}\text { 紫外緗: } \\
(\mathrm{W}) \\
\mathrm{MJ} / \mathrm{m}^{2} / \text { year }\end{array}$} & \multicolumn{2}{|c|}{ 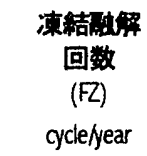 } & \multirow[t]{2}{*}{$\begin{array}{c}\mathrm{SO}_{2} \\
\text { 湿度 } \\
(\mathrm{SO}) \\
\mathrm{ppm}\end{array}$} \\
\hline & & & $S / 90$ & $N / 90$ & $S / 90$ & $N / 90$ & \\
\hline \multicolumn{8}{|l|}{ 政地点 } \\
\hline 善庭 & 1153 & $20.3 \quad 129$ & 128 & 57 & 171 & 160 & 0.005 \\
\hline つくば & 2724 & $24.4 \quad 17.5$ & 137 & 61 & 127 & 123 & 0.004 \\
\hline 大田 & 881 & $25.1 \quad 19.4$ & 138 & 61 & 36 & 25 & 0.011 \\
\hline 平坦 & 1451 & $25.4 \quad 19.5$ & 141 & 62 & 41 & 33 & 0.007 \\
\hline 尼蛙 & 636 & 25.620 .6 & 147 & 64 & 34 & 28 & 0.008 \\
\hline 沖永良部 & 1044 & $29.0 \quad 24.4$ & 160 & 70 & 0 & 0 & - \\
\hline
\end{tabular}

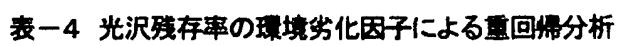

\begin{tabular}{|c|c|c|c|c|c|c|c|}
\hline \multirow[b]{2}{*}{ 試料 } & \multicolumn{6}{|c|}{$\begin{array}{c}\log \left(G / C_{0}\right)=C_{0}+\left(C_{W T} \cdot W T+C_{E T} \cdot E T+C_{W N} \cdot 1 W+C_{F Z} \cdot F Z+<N>\right) * Y_{r} \\
\text { の各綮数 }\end{array}$} & \multirow{2}{*}{$\begin{array}{c}\text { E相阙 } \\
\text { 係 } \\
R\end{array}$} \\
\hline & $C_{0}$ & $C_{W I}$ & $C_{t}$ & $C_{N}$ & $C_{F 2}$ & $\langle N\rangle$ & \\
\hline WHT & $1.73 \mathrm{E}-2$ & - & - & $-1.20 \mathrm{E}-3$ & - & - & 0.7714 \\
\hline YEL-O & $1.19 E-1$ & - & - & $-1.95 E-3$ & - & - & 0.8769 \\
\hline YEL-1 & $1.38 E-2$ & - & - & $-4.47 E-4$ & - & - & 0.7425 \\
\hline BLU & $-595 E-3$ & - & - & $-211 E-4$ & - & - & 0.5623 \\
\hline BLK & $-6.76 E-5$ & - & - & $-3.12 E-4$ & - & - & 0.4273 \\
\hline WHT & $1.69 \mathrm{E}-1$ & - & $8.34 E-3$ & - & - & - & 0.9153 \\
\hline YEL-O & $276 E-1$ & - & $-1.19 E-2$ & - & - & - & 0.9155 \\
\hline YEL-1 & $5.78 E-2$ & - & $-287 \mathrm{E}-3$ & - & - & - & 0.8169 \\
\hline BLU & $274 E-2$ & - & $-1.59 E-3$ & - & - & - & 0.7223 \\
\hline BLK & $4,75 E-2$ & - & $-231 E-3$ & - & - & - & 0.5421 \\
\hline WHT & $1.78 E-1$ & - & $-9.82 \mathrm{E}-3$ & $286 E-4$ & - & - & 0.9193 \\
\hline YEL-O & $256 E-1$ & - & $-8.38 E-3$ & $-6.83 E-4$ & - & - & 0.9264 \\
\hline YELA & $5.63 \mathrm{E}-2$ & - & $-260 E-3$ & $-5.26 E-5$ & - & - & 0.8179 \\
\hline BLU & $3.14 E-2$ & - & $-229 E-3$ & $1.36 \mathrm{E}-4$ & - & - & 0.7414 \\
\hline BLK & $5.28 \mathrm{E}-2$ & - & $-3.24 E-3$ & $1.80 E-4$ & - & - & 0.5540 \\
\hline WHT & $1.49 \mathrm{E}-1$ & 2.94E-5 & $-1.14 E-2$ & $3.28 E-4$ & $3.91 E-5$ & - & 0.9551 \\
\hline YEL-O & $278 \mathrm{E}-1$ & $5.06 \mathrm{E}-5$ & $-1.23 E-2$ & $-283 \mathrm{E}-4$ & $-4.71 E-4$ & - & 0.9509 \\
\hline YEL-1 & 3.87E-2 & $200 E-5$ & $-3.68 E-3$ & $-1.69 \mathrm{E}-5$ & $1.48 E-5$ & - & 0.9296 \\
\hline BLU & $2.28 E-2$ & $1.48 E-5$ & $-3.17 E-3$ & $1.83 E-4$ & $-227 E-5$ & - & 0.8730 \\
\hline BLK & $3.4 \mathbb{E}-2$ & $1.73 \mathrm{E}-5$ & $-4.12 E-3$ & $1.95 E-4$ & $3.81 \mathrm{E}-5$ & - & 0.6518 \\
\hline WHT & $1.5 \mathbb{E}-1$ & $266 E-5$ & $-8.10 E-3$ & $-2.79 E-4$ & $1.49 E-4$ & $-295 E-2$ & 0.9560 \\
\hline YEL-O & $266 \mathrm{E}-1$ & $6.2 \mathrm{ZI}-5$ & $-258 \mathrm{E}-2$ & $2222 E-3$ & $-9.27 E-4$ & $1.22 \mathrm{E}-1$ & 0.9582 \\
\hline YEL-1 & $4.00 \mathrm{E}-2$ & $1.87 \mathrm{t}-5$ & $-2.22 \mathrm{E}-3$ & $-288 E-4$ & $6.40 E-5$ & $-1.31 E-2$ & 0.9308 \\
\hline BLU & $2.36 E-2$ & $1.41 \mathrm{E}-5$ & $-234 E-3$ & $283 E-5$ & $5.28 E 6$ & $-7.49 \mathrm{E}-3$ & 0.8740 \\
\hline BLK & $3.50 E-2$ & $1.67 \mathrm{E}-5$ & $-3.32 E-3$ & $4.68 E-5$ & $6.50 E-5$ & $-7.21 E-3$ & 0.6522 \\
\hline
\end{tabular}

面」 ${ }^{15)}$ を参照した。

各暴露地点におけるこれらの值を表一 3 にまとめる。

5. 2 重回㷌分析

光沢残存率については，その対数 : $\log \left(G / G_{0}\right)$ を目的変数とし， 「4つの環境劣化因子と方位のうちのひとつ，およひ組み合わせた もの」と経過時間， $Y r(1 ， 2 ， 3 ， 4$ 年）の積を説明変数として重 回㷌分析を行った。目的変数のデータ数は，暴露地点（6箇所） $\times$ 方位（2条件）×経過時間（ 4 年）の積で $N=48$ となり，その結 果を表一 4 に示す。

補正後の明度 : $\Delta L-\Delta L_{W}$ を目的変数とする重回帰分析の結果を 表一 5 に, 有彩試料の $b^{*}$ 値の分析結果を表一 6 にそれぞれを整理す る。

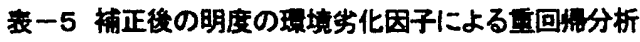

\begin{tabular}{|c|c|c|c|c|c|c|c|}
\hline \multirow[t]{2}{*}{ 試料 } & \multicolumn{6}{|c|}{$\begin{array}{c}\Delta L-\Delta L_{W}=C_{0}+\left(C_{W r} \cdot W T+C_{E} \cdot E T+C_{W N} \cdot\left(W+C_{F Z} \cdot F Z+<N>\right) * Y_{r}\right. \\
\text { の各保数 }\end{array}$} & \multirow{2}{*}{ 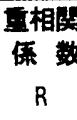 } \\
\hline & $C_{0}$ & $G_{W r}$ & $C_{E}$ & $C_{o r}$ & $C_{F Z}$ & $\langle N\rangle$ & \\
\hline YEL-O & 1.89 & - & - & $4.34 E-3$ & - & - & 0.3079 \\
\hline YEL-1 & 1.22 & - & - & 6.59E-3 & - & - & 0.4220 \\
\hline BLU & $5.93 \mathrm{E}-1$ & - & - & $2.17 \in-2$ & - & - & 0.6224 \\
\hline BLK & 2.00 & - & - & $1.98 E-2$ & - & - & 0.5419 \\
\hline YEL-O & 2.75 & - & 4.49E-3 & - & - & - & 0.0546 \\
\hline YEL-1 & 1.60 & - & 2.37E-2 & - & - & - & 0.2597 \\
\hline BLU & -233 & - & $1.54 E-1$ & - & - & - & 0.7544 \\
\hline BLK & -1.60 & - & $1.57 \mathrm{E}-1$ & - & - & - & 0.7366 \\
\hline YEL-O & 3.25 & - & $-8.34 E-2$ & $1.70 E-2$ & - & - & 0.5620 \\
\hline YEL- & 201 & - & $-4.84 E-2$ & $1.39 E-2$ & - & - & 0.4885 \\
\hline BLU & -2.55 & - & $1.93 \mathrm{E}-1$ & $-7.46 \mathrm{E}-3$ & - & - & 0.7609 \\
\hline BLK & -2.15 & - & $2.55 E-1$ & $-1.88 \mathrm{E}-2$ & - & - & 0.7743 \\
\hline YEL-O & 3.26 & $1.86 E-5$ & $-8.47 \mathrm{E}-2$ & $1.71 \mathrm{E}-2$ & $-1.26 \mathrm{E}-4$ & - & 0.5622 \\
\hline YEL-I & 2.16 & $2.51 E-5$ & $-5.26 \mathrm{E}-2$ & $1.4 \pi E-2$ & $-1.26 \mathrm{E}-3$ & - & 0.4940 \\
\hline BLU & -3.80 & $-3.21 E-4$ & $237 \mathrm{E}-1$ & $-1.51 \mathrm{E}-2$ & $1.14 E-2$ & - & 0.8118 \\
\hline BLK & -3.34 & $-3.64 E-4$ & $3.00 E-1$ & $-264 E-2$ & $1.12 E-2$ & - & 0.8160 \\
\hline YEL-O & 3.42 & $-1.32 \mathrm{E}-4$ & $9.02 \mathbb{E}-2$ & $-1.53 \mathrm{E}-2$ & $5.77 \mathrm{E}-3$ & -1.58 & 0.6116 \\
\hline YEL-1 & 2.22 & $-3.53 \mathrm{E}-5$ & $1.75 E-2$ & $1.73 E-3$ & $1.11 E-3$ & $-6.32 \mathrm{E}-1$ & 0.5016 \\
\hline BLU & -3.95 & $-1.85 \mathrm{E}-4$ & $7.79 E-2$ & $1.43 E-2$ & $6.06 E-3$ & 1.43 & 0.8165 \\
\hline BLK & -3.56 & $-1.65 E-4$ & $6.88 \mathrm{E}-2$ & $1.65 \mathrm{E}-2$ & 3.35E-3 & 208 & 0.8252 \\
\hline
\end{tabular}

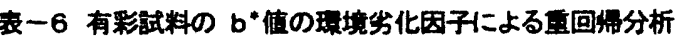

\begin{tabular}{|c|c|c|c|c|c|c|c|}
\hline \multirow[b]{2}{*}{ 尌料 } & \multicolumn{6}{|c|}{$\begin{array}{c}\Delta b^{*}=C_{0}+\left(C_{W r} \cdot W T+C_{E E} \cdot E T+C_{W} \cdot\left(W+C_{Z Z} \cdot F Z+<N>\right) * Y_{r}\right. \\
\text { の各你数 }\end{array}$} & \multirow{2}{*}{$\begin{array}{c}\text { 晋相闻 } \\
\text { 係 数 } \\
\mathrm{R} \\
\end{array}$} \\
\hline & $C_{0}$ & $C_{W T}$ & $C_{E T}$ & $C_{N}$ & $\mathrm{C}_{\mathrm{FZ}}$ & $\langle N\rangle$ & \\
\hline YEL-O & -274 & - & - & $-5.62 \mathrm{E}-2$ & - & - & 0.7955 \\
\hline YEL-1 & -5.63 & - & - & $-258 \mathrm{E}-2$ & - & - & 0.6318 \\
\hline BLU & 1.29 & - & - & $2.19 \mathrm{E}-2$ & - & - & 0.7118 \\
\hline YEL-O & 297 & - & $-3.64 E-1$ & - & - & - & 0.8837 \\
\hline YEL-I & -2.38 & - & $-1.79 \mathrm{E}-1$ & - & - & - & 0.7498 \\
\hline BLU & -1.50 & - & $1.52 E-1$ & - & - & - & 0.8474 \\
\hline YEL-O & 285 & - & $-3.43 \mathrm{E}-1$ & $-4.16 \mathrm{E}-3$ & - & - & 0.8841 \\
\hline YEL-A & -220 & - & $-210 E-1$ & $6.13 E-3$ & - & - & $0.7530^{\circ}$ \\
\hline BLU & -1.66 & - & $1.81 \mathrm{E}-1$ & $-5.55 E-3$ & - & - & 0.8515 \\
\hline YEL-O & 5.35 & $1.58 \mathrm{E}-3$ & $-4.96 E-1$ & $1.66 \mathrm{E}-2$ & $-283 E-2$ & - & 0.9385 \\
\hline YEL-1 & -1.21 & $3.85 E-4$ & $-2.54 E-1$ & $1.29 \mathrm{E}-2$ & $-9.78 E-3$ & - & 0.7781 \\
\hline BLU & -259 & $-4.89 \mathrm{E}-4$ & $231 \mathrm{E}-1$ & $-1.27 \mathrm{E}-2$ & $9.91 \mathrm{E}-3$ & - & 0.8888 \\
\hline YEL-O & 5.17 & $1.74 E-3$ & $-6.82 \mathrm{E}-1$ & $5.12 \mathbb{E}-2$ & $-3.46 E-2$ & 1.68 & 0.9399 \\
\hline YEL-1 & -1.06 & $242 E-4$ & $-8.81 E-2$ & $-1,78 \mathrm{E}-2$ & $-4.19 \mathrm{E}-3$ & -1.49 & 0.7821 \\
\hline BLU & -2.69 & $-3.92 \mathrm{E}-4$ & $1.18 \mathrm{E}-1$ & $8.19 E-3$ & $6.12 \mathbb{E}-3$ & 1.01 & 0.8916 \\
\hline
\end{tabular}




\section{6. 考察}

\section{1 相当環境温度と柴外線}

光沢残存率 ……時間経過とともに減少しており，「相当環境温度, $E T$ 」よび紫外線，UV」の係数はマイナスとなっている。ET との相関係数が $U V$ のそれより大きいことは，「柴外線量のみで耐 候性を説明する」ことには限界があることを示している。「ET と $U V 」$ 」相乗効果をみると, 相関係数の上昇は僅かで $U V$ の係数に はプラスの場合もあって，これまでの認識とは異なるように思われ るが，「日射量データ」のみから UVが推定されるのに対して，ET は，その算出の基となるブラックパネル温度を推定する際に「気温」 と「日射量データ」を参照しており，既に「紫外線と熱」の相乗効 果を取り込んだ指標となっているためである。

.補正後の明度 …明るい黄色試料では, 時間経過に関わらず一定 であって，ET・UV ともに相関性はなく，地域差も認められない。 暗色の青色と黒色試料では明度が上昇して，ET のみの相関係数が $U V$ みより大きく，ETと $U V$ の相乗効果も少ない。

$b^{*}$ 值 …0 0 に近づいて絶対值が減少するような, 鮮やかさが失わ れる。ETのみの相関係数は $U V$ のみより大きく，相乗効果も少な い。

\section{2 結露時間・凍結融解・方位係数}

$E T$ と $U V$ に加え,「結露時間, $W T$ ・「凍結融解回数, $F Z$ 」「方 位係数, <N>」を追加することで, 説明変数が増えたことで重相 関係数は上昇する。

光沢残存率 …WT $\cdot F Z \cdot\langle N>$ の効果は顔料種によって様々で はあるが, ET は常にマイナスの值となっており主要な指標である ことが裹づけられる。

補正後の明度 …明るい黄色試料では, 説明変数の種類が増えて も, 先に述べたように, 明度は時間経過に関わらず一定であるため, その効果は少ない。暗色試料では，ETの伱数はプラスである。FZ の俰数もプラスで，物理的な作用によって明度上昇に寄与している ことが推察される。

$b^{*}$ 値 …ETO保数は黄色試料ではマイナス, 青色試料ではプラ スのままである。FZの係数の正負は $E T$ と同じで, 鮮やかさが失わ れることに奇与している。

全評価項目に共通して，WT の係数の正負はETの係数とは逆で ある。絶対湿度が一定であれば気温が高くなると相対湿度が低下す るため, 主に相対湿度によって決まる WT は気温が高いと低下する 11)。ブラックパネル温度より求められる ET は, 6.1 で述べたよう に気温と日射量の増加によって高くなる。本報で扱っている試料の 温度は，ブラックパネルほど高くならないので, $E T$ を説明変数と して導入したことで, 結果的に「温度や日射量の効果が, 過剩に影 響している」可能性があり，それを補正するため，WT の係数が $E T$ と正負が異なるのだろう。垂直面での WT が得られていない段 階での考察は，今後精査の上修正されることも考えられる。

\section{6. $3 \mathrm{SO}_{2}$ 濃度の影響}

高分子素材の劣化には，酸性雨の影響がある ${ }^{16 \sim 17)}$ とされている。 沖永良部以外の 5 ヶ所の暴露地点で, 大気污染状況が観測されてい る $^{18)}$ ので, $\mathrm{SO}_{2}$ 濃度 $(S O)$ の年平均の観測結果を表一 3 に示す。 沖永良部を除く 5 地点について $(N=40)$ ，説明変数に $S O$ を追加し た場合を表一 7 に示す。
$S O$ の観測值の精度は他の因子に比べて低いので，重回帰分析の 結果として得られたその係数 : $C$ so の意味は吟味されればならない が、「酸性雨の影響」とも思われる特性変化の兆候を示寸試料もみら れる。

光沢残存率 …S SO 考慮しない場合に比べて, 試料:BLU・BLK では相関保数が上昇し，SO の係数はマイナスであることからこ れらの試料では $\boldsymbol{S O}$ 㘯特性変化に奇与している。 $\mathrm{SO}_{2}$ 濃度は「大田 が高いことで図ー 1 との対応がある。他の大気污染物質が大きく 関係していることも考えられるので, 今後 $\mathrm{SO}_{2}$ 成分のみを選択的 に作用させるような，室内促進耐候性試験などに基づいた考察が必 要と思われる。

補正後の明度 …SO $S O$ を導入しない段階で, YEL-O の重相関係数 が表ー 5 で 0.6116 であった值に比べ，沖永良部を除いた 5 地点のみ の表一 7 では 0.9180 に上昇している。本報では考慮していない沖永 良部特有の環境因子，例えば前報 ${ }^{8)}$ で塩分の作用に着目したが，こ の供試塗料に限って強く作用していたことが取り除かれたためとも 考えられる。SO を説明変数に加えることは，表一 7 に示すように 重相関係数は変わらないか, 僅かな増加にとどまり, 効果は少ない。

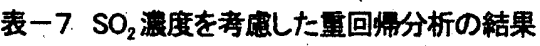

\begin{tabular}{|c|c|c|c|c|c|c|c|c|}
\hline \multirow[b]{2}{*}{ 敦料 } & \multicolumn{7}{|c|}{ 環境劣化因子による吾回带式の各係数 } & \multirow{2}{*}{$\begin{array}{c}\text { 重相関 } \\
\text { 係 数 } \\
\mathrm{R}\end{array}$} \\
\hline & $C_{0}$ & $C_{\text {Wr }}$ & $C_{E}$. & $G_{N}$ & $C_{2}$ & $\langle N\rangle$ & $\mathrm{C}_{\mathrm{SO}}$ & \\
\hline 光沢 & \multicolumn{8}{|c|}{$\log \left(G G_{W_{0}}\right)=C_{0}+\left(C_{W r} \cdot W T+C_{E} \cdot E T+C_{V V} \cdot U V+C_{Z_{2}} \cdot F Z+<N>+C_{S 0} \cdot S O\right) * Y_{r}$} \\
\hline WHT & $1.54 \mathrm{E}-1$ & $2.41 E-5$ & $4.40 E-4$ & $-1.79 E-3$ & $2.30 E-4$ & $-9.69 E-2$ & - & 0.9468 \\
\hline YEL-O & $2.44 E-1$ & 4.7OE-5 & $-9.66 \mathrm{E}-3$ & $-5.16 E-4$ & $-6.26 E-4$ & $1.56 \mathrm{E}-2$ & - & 0.9763 \\
\hline YEL-I & $4.84 E-2$ & $1.57 E-5$ & $6.19 E-4$ & $-8.43 E-4$ & $1.63 \mathrm{E}-4$ & $-3.57 E-2$ & - & 0.9245 \\
\hline $\mathrm{BLU}$ & $2.28 \mathrm{E}-2$ & $1.40 E-5$ & $-1.78 E-3$ & $-873 E-6$ & $-4.61 E-5$ & $-9.03 E-3$ & - & 0.8704 \\
\hline BLK & $1.58 E-2$ & $1.49 E-5$ & $3.80 E-4$ & $-3.19 E-4$ & $-1.12 E-4$ & $-2.06 E-2$ & - & 0.8360 \\
\hline WHT & $1.53 \mathrm{E}-1$ & $3.65 E-5$ & $-4.23 E-3$ & $-1.65 E-3$ & $3.91 E-4$ & $-1.07 E-1$ & 9.15 & 0.9591 \\
\hline YEL-O & $2.44 E-1$ & $4.35 E-5$ & $-9.00 E-3$ & $-4.95 E-4$ & $-6.42 E-4$ & $2.12 \mathrm{E}-2$ & -1.86 & 0.9765 \\
\hline YEL-1 & $4.94 E-2$ & $6.66 \mathrm{E}-6$ & $2.37 \mathrm{E}-3$ & $-7.89 E-4$ & $1.20 E-4$ & $-207 E-2$ & -4.91 & 0.9420 \\
\hline BLU & $2.3 \pi-2$ & $5.98 E-6$ & $-235 E-4$ & $3.96 \mathrm{E}-5$ & $-8.37 \mathrm{E}-5$ & $4.17 E-3$ & -4.35 & 0.9285 \\
\hline BLK & $1.71 E-2$ & $3.63 E-6$ & $2.55 E-3$ & $-2.52 \mathrm{E}-4$ & $-1.65 E-4$ & $-2.05 E-3$ & -6.10 & 0.9670 \\
\hline \multicolumn{9}{|c|}{$\begin{array}{r}\Delta \mathrm{L}-\Delta \mathrm{L}_{\mathrm{w}}= \\
\end{array}$} \\
\hline YEL-O & -6.58 & $-4.12 \mathrm{E}-5$ & $2.39 E-2$ & $-2.94 E-2$ & $2.92 E-3$ & 3.86 & - & 0.9180 \\
\hline YEL-1 & 2.48 & $-9.32 \mathrm{E}-5$. & $7.34 E-2$ & $-9.32 E-3$ & $2.93 E-3$ & -1.09 & - & 0.4835 \\
\hline$B L U$ & -4.16 & $-3.60 E-4$ & $2.65 E-1$ & $-1.75 E-2$ & $9.34 E-3$ & $1.94 E-1$ & - & 0.8246 \\
\hline BLK & -3.98 & $-3.10 E-4$ & $2.22 \mathrm{E}-1$ & $-8.91 E-3$ & $6.21 \mathrm{E}-3$ & 1.12 & - & 0.8249 \\
\hline YEL-O & -6.57 & $-1.57 E-4$ & $4.62 E=2$ & $-2.87 \mathrm{E}-2$ & $2.38 E-3$ & 4.05 & -629 & 0.9183 \\
\hline YEL-1 & 2.48 & $-9.42 E-5$ & $7.36 E-2$ & $-9.31 E-3$ & $2.92 \mathrm{E}-3$ & -1.09 & -0.546 & 0.4835 \\
\hline BLU & -4.20 & $-3.23 E-5$ & $2.02 E-1$ & $-1.94 E-2$ & $1.09 E-2$ & $-3.45 E-1$ & 178 & 0.8317 \\
\hline BLK & -4.01 & $-6.74 E-5$ & $1.75 E-1$ & $-1.04 E-2$ & $7.35 E-3$ & $7.20 E-1$ & 131 & 0.8283 \\
\hline$b$ *值 & $\Delta b^{*}=c_{0}+1$ & $=W T+C_{E} \cdot$ & $-E T+G_{V^{-}} \cdot$ & $U N+C_{+2} \cdot F_{Z}$ & $Z+\langle N\rangle+$ & $\left.+\mathrm{C}_{S O} \cdot \mathrm{SO}\right) *$ & & \\
\hline YEL-O & 5.42 & $1.80 E-3$ & $-6.89 E-1$ & $5.75 E-2$ & $-4.09 E-2$ & 1.89 & - & 0.9516 \\
\hline YEL-1 & $-1.63 E-1$ & $2.97 t-4$ & $-1.68 E-1$ & $-9.12 E-3$ & $-263 E-3$ & -1.22 & - & 0.8031 \\
\hline BLU & -3.20 & $-4.50 E-4$ & $1.91 \mathrm{E}-1$ & $-1.68 E-3$ & $6.00 E-3$ & $6.65 E-1$ & - & 0.9066 \\
\hline YEL-O & 5.39 & $2.03 E-3$ & $-7.34 E-1$ & $5.61 E-2$ & $-3.98 E-2$ & 1.51 & 125 & 0.9524 \\
\hline YEL-I & $-1.58 E-1$ & $2.55 E-4$ & $-1.59 E-1$ & $-8.86 E-3$ & $-2.82 E-3$ & -1.15 & -22.7 & 0.8032 \\
\hline BLU & -3.26 & $4.55 E-5$ & $9.51 E-2$ & $-4.66 E-3$ & $8.32 E-3$ & $-1.49 E-1$ & 269 & 0.9250 \\
\hline
\end{tabular}


$b^{*}$ 值 …表一 6 に示した 6 地点の值に比べて, 沖永良部のデータ を除いた表一 7 の值では，重相関保数は若干上昇する。これに $S O$ の影響を考虑すれは，重相関保数はいくらか大きくなる。

\section{7. まとめ}

本報で扱った着色塗料の屋外暴露詿跧とその重回帰分析の結果か ら得られた知見は以下のとおりである。

1）時間経過と共に光沢減少・彩度低下が認められ，これを種々の 環境劣化因子」によって重回州分析を行ったところ，相関が高い 因子が抽出できた。

環境劣化因子である，「紫外線」，および「ブラックパネル温度に 基づく相当環境温度」は，特性変化と相関が高く，地域差の指標に なる。特に相当環境温度は，日射量の効果を含んでおり，紫外線量 よりも有効である。凍結融解作用了は，物理的な特性変化因子とし て作用する試料もあった。「結露時間」は，「相当環境温度」による 過剩な熱劣化作用を補正するような効果があり得る。

2）白色梁料の明度低下量で，他の着色深料の明度変化を補正した ところ，明色塗料では， 1 年経過した後，一定の飽和状態に達し， 環境劣化因子の影響はほとんどない。暗色叙料では経時的な明度上 昇があり，環境少化因子が作用することで説明できる。

3）従って，これまで「色差」を指標として塗料の耐侯性を評価し ていたが，その成分 : 明度と彩度は，それぞれ別の因子が作用して 特性変化も異なるため，解析精度を高められなかった獎念がある。

\section{参考文献}

1）建設省建築研究所，日本建築仕上材工業会：建築用仕上筀材の酎

久性能に関する研究 (共同研究最終報告書), 平成 2 年 1 月

2）日本叙料工業会・酎候性研究会：建築粠造用叙料の㓦候性に関す る调查研究 [ 報告畫・第 1 報], 平成 9 年 10 月

3）日本塗料工業会・耐候性研究会：建築粠造用塗料の耐候性に関す る調查研究 [ 報告書・第 2 報 ], 平成 12 年 10 月

4）(社）建築業協会・高耐候性材料評価研究会（岩井孝饮，矢野瑞䅹

ほか)，外壁用塗料の酎候性評価に関する研究（その 1 43），日本 建築学全大会学術講演梗概集・A, 1991 2000年

5）景珤材料の美旣性維持に関する調查研究委員会:景観維持に関する
調查報告（その 3$) ，($ 社）日本建材産業協会，平成 12 年 3 月

6) 新発電システムの標淮化に関する調查研究委員会（塗料系分科 会) : 新発電システムの標準化に関する調查研究 (新発電関連要蜏機 器の長期酎久性及び寿命予娜の標泩化）成果報告書，(財）日本ウェ ザリングテストセンター

7) JIS Z 8730 色差表示方法

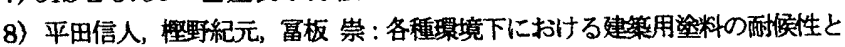
酎污染性の評価，日本建策学会梅造系論文集，No.553, pp.19-25, 2002.3

9) Jonathan W. Martin: A Systems Approach to the Service Life Prediction Problem for Coating Systems, Proceedings of Corrosion 97 Research Topical Symposia(New Orleans), The National Association of Corrosion Engineers, pp.235-256, 1997

10) T. Ogawa: Numerical Prediction of Weatherability by Applying the Method of Multivariate Analysis for Plastic Film, Proceedings of 5th international symposium on weatherability(Tokyo), Material Life Society, Japan, pp.85-90, 2002.10

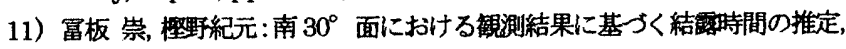
日本建築学会楼造系論文集，No.563, pp.29-35, 2003.1

12）冨板 甞: 水平・傾斜・垂直面でのブラックパネル温度に基つく熱による特 性変化予想マップ，日本建案学会棈造系論文集，No.538, pp.43-47, 2000.12

13）柖木 堯, 富板 崇: 国内の紫外域日射量マップ, 建築研究資料, No.60, 建設省建策研究所, 1987.3

14）冨板 崇: 傾斜・垂直面に拄ける紫外線量の推定手法，日本建築学会構造系 論文集, No.535, pp.29-34, 2000.9

15）富板 崇, 檉野紀元，济崎 仁：国内各地でのブラックパネル温度に基つくく

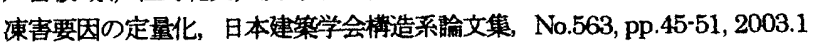

16) G. Frohnsdorff and L. W. Masters: The Meaning of Durability and Durability Prediction, Procedings of 1st Durability of Building Materials and Components, pp.18-30, Ottawa, 1978

17) JIS Z 2381 大気暴露試験方法通則

18）国立境研究所・環境データベース「大気璄境月間值・年間值デ 一タファイル」

19) Atlas Electric Devices Company: Weathering Testing Guidebook, 2001

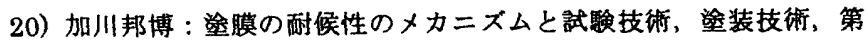
41 巻 11 号, pp.53-62, 2002.10

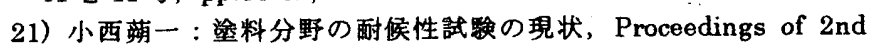
international symposium on weatherability(Kaw aguchi), Material Life Society, Japan, pp.34-44,1994.9

（2003年 1 月 24 日原稿受理, 2003年 6 月 26日採用決定） 